\title{
Action Research: A Strategy for Instructional Improvement
}

\section{Carol Reed}

\begin{abstract}
A ction Research gives teachers the skills needed to work on problems specific to their classrooms and their schools. By using an actual research procedure, researching teachers can resolve their own teaching challenges. They learn how to ask a focusing question, define terms, collect relevant data, use an analysis process that rules out bias, and includes methods that yield validity and reliability.
\end{abstract}

The findings become immediately applicable to their individual situations. For example: Jeremy's third-grade teacher watched him out of the corner of her eye. Though he sat quietly reading, she knew that he could, and often did, erupt into loud, emotional displays. On this particular day, the eruption came just after recess. Inexplicably, Jeremy jumped up, swept papers off his desk, and with a loud roar, tipped the desk over. The teacher managed to get him out of the classroom and into the safety of the nurse's office while his classmates patiently straightened his desk and gathered his scattered belongings. Still, in spite of their practiced efficiency, a half-hour passed before the teacher could get the class settled and working again. Totally frustrated with the repeated loss of teaching time and the months it takes to complete Special Education referrals, the teacher decided to try what she learned in an Action Research class. She did a little Action Research project on Jeremy: First, the question: In this case, it was simple. What upsets Jeremy? Next, data collection: It was a little tougher to decide how to collecting formation that might respond to the question. It was tempting to think of the problem as originating in the home, on the playground, or within his psychological make-up.
But true as that may have been, knowing it didn't do much for the classroom. Perplexed, the teacher decided to make brief notes about what happened immediately before each disruption. Then, data analysis: Several disruptions later, the teacher spread the collected data that is the notes, across her desk reading them over and over, looking for patterns. Suddenly, she had it. The findings: Jeremy erupted when she passed out papers asking students to work on new concepts. The action plan: Gently confronting Jeremy with the "evidence," led to information that earlier "interrogations" had not revealed. Jeremy tearfully confessed that he always felt afraid he that could not do the new assignment. Together, they worked up a plan. When the teacher passed out work on new concepts, she promised to hand Jeremy a "fun" paper to work on. Jeremy agreed to practice patience. Thereafter, the teacher first got the rest of the class working well, then went to Jeremy's desk and helped him with the new concept until they both felt that he understood what to do. And it worked! The disruptions diminished significantly until; finally, the teacher withdrew her recommendation for a Special Education referral.

The same process works equally well in larger situations. For example: a middle school teacher, sitting in her staff lounge casually thumbing through a magazine, found an article citing research which alleged that high school dropouts make their decision to quit school during their middle school years. The teacher could not get the allegation out of her mind, repeatedly asking herself, "How does that happen?" "What do we do?" She, too, decided to implement an ac- tion research process.

First, the question: After considerable struggle and consultation, she chose: "What can this school do to make the transition from elementary to middle school "user friendly?" Next, data collection: The teacher constructed a simple survey asking about various student experiences during students' transition time which she administered to her own sixth grade class. Startled by the students' response, the teacher enlisted the help of the school counselor. Together they surveyed two school wide randomly selected groups, one group consisting of "at-risk" students, the second of "average" students with the groups matched for gender and ethnic representation

Then data analysis: The teachers read through the surveys to find patterns in the responses and listed rubrics for the patterns (often called themes). Then they again read through the surveys to tally responses that fit under each pattern, a tally they could graph. The findings: A significant number of students in both groups felt overwhelmed by the social challenge of being relatively anonymous in a large school setting.

The action plan: The teacher, the counselor, and the principal shared the information with the faculty who were, in turn, stunned. Student responses such as, "None of the teachers seem to know my name," and "No one speaks to me" tugged at their heart strings. The group not only faced up to the challenge by developing multiple plans that responded to revealed student information, they "commissioned" additional surveys that year and subsequent years to check their success in responding to the findings from the initial survey. Parents, impressed with the school's growing Action Research efforts, asked for the school's cooperation in surveying parents about the same issue. Eventually, other middle schools asked for information and adjusted their own transition plans accordingly. 


\section{TEACHING \& LEARNING}

The process works equally well for curriculum issues. For example, two teachers, working on separate projects in different time periods and at different levels, wanted to check the rumor that students who write down the thought process they use when they solve math problems actually do better in math. The elementary school teacher compared the length of time it took specific students to master specific skills when he taught in his standard manner, and then when he had students write out their thinking. The high school teacher compared three different classes grouped into underachiever, average, and advanced. The first year, he required only the underachievers to write. By the end of the year, that class had average test scores that exceeded those of the average group. The next year, he required all three levels to write and all three made greater than usual progress, but the underachievers still made the most progress. Both teachers wondered how much of the progress was due to their ability to "see" the glitches in their students' thinking, which allowed them to respond with appropriate pedagogy.

In another school, a first year primary teacher, feeling confident about her spelling program and wanting to document its success, could barely pose a pedagogical question. She was already sure she had an effective way to teach spelling. What she did do was collect data: lists, and charts, and spelling profiles, as well as stories and sentence work. In January she administered a comprehensive test of the first semester's words. To her horror, most of the children failed it! Though temporarily undone, she resolutely pulled out her data and poured over it, finally determining that her program led students to use a broadened vocabulary in their sentences and their stories which was a good result, but she learned that she had more work to do on teaching for retention. Sometimes, some schools actually become centers of inquiry. In one instance a new elementary school principal, who looked so young that on his first day a teacher asked if he had come from the local high school to tutor, faced a staff of senior teachers. Respecting their experience and confidence, he began school improvement through gently administered Action Research projects. For example, one teacher coming into the lunch room after a frustrating morning sank into a chair saying, "Why does it take so long to get those children settled down after recess?" The principal, after a space of time and using his youthfulness to make his response credible, replied, "That is such a good question. Why does it take so long to get those children settled down after recess? How could we find out?" The assembled group offered suggestions for collecting relevant information, that is, good data sources. They analyzed the information at the next teachers' meeting and set up an action plan based on their findings. Changed recess procedures solved the problem. By the end of the second year, at any given time, at least half the teachers worked on research projects with questions ranging from, "Why don't our children make better scores on those reading tests?" to "How can we get them to eat their lunches?" As a side result, no one missed teachers' meetings, or even came late. Relevant stuff was happening there!

A local high school became a center of inquiry over a three-year period by sending a number of teacher-leaders through Action Research coursework with each working on separate projects. In the words of one (whose initial project could barely be called Action Research), "You know, I'm beginning to see the long-term effect of this. It isn't just what we learn from our projects. It's an attitude about teaching. When we have a problem in this school, we don't just sit around and complain about it anymore. We face up to it. We ask the question. We collect information. We solve our problem. In a way, we've
4:2 Fall 2007

taken control of our professional lives."

In each of the descriptions above, teachers identified the problem, teachers chose the question, collected and analyzed the data, and teachers developed action plans based on findings. One huge gap in the evaluations developing around the current drive for accountability is that it often does not allow for a process that teachers themselves can use to solve their own problems, to evaluate the effect of their own teaching practices. That's what Action Research, in its current reincarnation, is intended to do. And, that is how it can be most helpful.

\section{Recommended Reading:}

Anderson, G. L., Herr, K. \& Nihlen, A. S. (1994). Studying your own school: An educator's guide to qualitative practitioner research. Thousand Oaks, CA: Corwin Press.

Brooks, A. \& Watkins, K. E. (Eds.) (1994). The emerging power of action inquiry technologies. San Francisco: Jossey-Bass Publishers.

Glanz, Jeffrey. (2003). Action Research: An Educational Leader's Guide to School Improvement. Christopher-Gordon.

Glesne, C. \& Peshkin, A. (1992). Becoming qualitative researchers: An introduction. Urbana/Champaign: Longman. Hubbard, Ruth Shagoury and Brenda Miller Power. (1993).

McKernan, J. (1991). Curriculum action research: A handbook of methods and resources for the reflective practitioner. New York: St. Martins Press.

McLean, J. E. (1995). Improving education through action research: A guide for administrators and teachers. Thousand Oaks, CA: Corwin Press.

Nodie, Oja, S. \& Smulyan, L. (1989). Collaborative action research: A developmental approach. New York: The Falmar Press.

Olson, M. W. (Ed.). (1990) Opening the door to classroom research. Newark, DE: International Reading Association.

Reed, Carol. (2000). Teaching With Power: Shared Decision-Making and Classroom Practice. New York: Teachers College Press. 


\section{4:2 Fall 2007}

Sagor, R. (1992). How to conduct collaborative action research. Alexandria, VA: ASDC Whyte, W. F. (1991). Participatory action research. Newbury Park, CA: Sage Publications.

The Art of Classroom Inquiry. Portsmouth, New Hampshire: Heinemann. Livingston, C. \& Castle S. (1989). Teachers and research in action. Washington, DC: National Education Association .

Copyright $\odot$ March 2002, New Horizons for Learning, all rights reserved.

http://www.newhorizons.org

E-mail: info@newhorizons.org

For permission to redistribute, please go to:

New Horizons for Learning Copyright and Permission Information

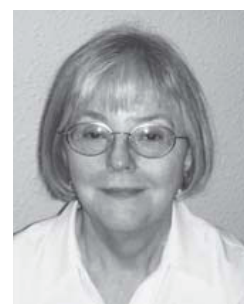

Carol Reed, a long-time elementary school teacher whose research interest is social and organizational change is also served as a teacher advocate. Dr Reed was first president of her local teachers' association and then worked as a project facilitator charged with supporting teacher leaders in a school change initiative that involved twenty-one elementary and secondary schools. She also worked as the project director of a teacher leadership program in a consortium that included fifteen school districts and a local university before becoming an associate director of the consortium. Currently, Dr. Reed teaches professional development classes and consults on social and organizational change issues. Her book, Teaching With Power: Shared Decision-Making and Classroom Practice is available form Teachers College Press.

\section{A Simple Plan for Action Research (Part B)}

$\Gamma$ eachers interested in Action Research Projects in schools should be aware that there is much speculation as to the transferabil-

TEACHING \& LEARNING

ity of the results to larger populations. But this should not necessarily detract teachers from in-class research because the primary purpose of the majority of teacher initiated research is most often directed at changing and improving what happens in the classroom or in a particular school rather than at a board or whole system level. Institutional constraints on what might be investigated and how the sharing of results might compromise existing policies regarding personal information sharing and confidentiality are always an issue within institutionalized contexts and could impede the novice researcher. Yet as Paula Friere argued action research, particularly that described as Participatory Action Research or (PAR) is best suited to those willing to critically analyze and make connections between learning and the act of transformational change within political realities. A paragraph taken from Theresa Thorkildsen book "Fundamentals of Measurement in Applied Research" Allyn and Bacon, 2005 pg. 423 sums up what is generally expected of those interested in pursuing action research projects.

Action researchers engage in reoccurring cycles progressing from action, to reflection, to practical theorizing to the generation of new ideas and back to action. Educators, clinicians and other professionals try to achieve two goals. They are looking for thoughtful, practical ways to improve their own work, and sharing their professional discoveries with others.

Action research has typically six defining features:

Investigators are the agents in situations being researched.

Research starts with a practical problem and questions that emerge from a particular setting.

Actions are compatible with the values upheld in the setting.

Decisions are made by considering a cost to cost benefit ratio in which investigators maximize practical benefits with out diminishing preexisting results.

Action and reflection are closely linked mechanism by which investigators develop their own actions and knowledge.

The nature of the problem rather than standardized procedures shapes the process and the results.

According to J. Rogers the tools of the teacher researcher include identifying a problem and clarifying a research question. Survey techniques, questioning and reflective strategies are important references points to ensure that the research question is the correct one. After one is sure of the premise, and objective, employ a strategy or intervention (action) that is aimed at changing or improving the problem at hand. Analyze the data appropriately with appropriate statistical tools. Assess outcomes and report these with plans and recommendations for future practice or study. (Rogers 2000).

It is important for anyone involved to understand that one of the fundamental principles of action research methodology particularly that called Participatory Action Research is that the ultimate goal of research is the radical transformation of social reality and the improvement of lives of the people involved. The beneficiaries of the research are the members of the community itself not the researchers. (Hall 1975) cited in Ryan and Robinson 1990.

As George Richardson and all the other contributing authors in this issue have reiterated there are a variety of projects that require attention including diversity and citizenship issues, collaboration and involvement, disparities in learning opportunities and self-becoming experiences, leadership and caring in institutional environments and the betterment of learners within the context of professional trust. 